\title{
Relationship between Children's Body Mass Index and Parents' Obesity and Socioeconomic Status: A Multilevel Analysis Applied with Luxembourg Data
}

\author{
Anastase Tchicaya, Nathalie Lorentz \\ Living Conditions/Health Research Team, CEPS/INSTEAD, Esch-sur-Alzette, Luxembourg \\ Email: anastase.tchicaya@ceps.lu
}

Received 18 July 2014; revised 3 September 2014; accepted 19 September 2014

Copyright (C) 2014 by authors and Scientific Research Publishing Inc.

This work is licensed under the Creative Commons Attribution International License (CC BY). http://creativecommons.org/licenses/by/4.0/

(c) (i) Open Access

\begin{abstract}
Obesity in children is a health crisis because the problem is increasing in most developed countries. This study measures the relationship between body mass index (BMI) of children aged 7 - 12 years residing in Luxembourg and the weight and socioeconomic status of their parents. The data used are from the 2007 Socio-Economic Panel Liewen zu Lëtzebuerg/European Union-Statistics on Income and Living Conditions survey, which covers a population of approximately 10,000 people. The study sample includes $\mathbf{7 7 5}$ children whose weight and height were recorded to calculate their BMI. The descriptive analysis with the socioeconomic distribution of the children's BMI and the multilevel logistic regression of the probability to be in overweight or obese were performed. The mean BMI of children was $17.4 \mathrm{~kg} / \mathrm{m}^{2}$ for boys and girls. The prevalence of overweight was $21.2 \%$ (including 3\% who were obese). Weight status, educational level, physical activity, and eating habits of parents were associated with BMI in children. Furthermore, children of foreign nationality had 2.9 times more risk to be overweight or obese than other children of Luxembourg nationality $(\mathrm{OR}=2.90,95 \% \mathrm{CI}: 1.38-6.10)$. Children living in household with at least one parent who was obese were 6.51 times more likely to be in overweight or obese compared to those in household with both parents normal $(O R=6.51,95 \% C I: 2.48-17.08)$. Overall, nationality and weight status of parents were the main determinants of children's weight status. Promoting healthy diets and regular physical activity and educating parents on the consequences of overweight and obesity on children's health in adulthood are effective strategies to control overweight and obesity.
\end{abstract}

\section{Keywords}

BMI, Obesity, Children, Socioeconomic Status, Luxembourg 


\section{Introduction}

Obesity in children is a health crisis [1]. The prevalence of overweight and childhood obesity is rising in most developed and urbanized areas [1]. Obesity in childhood is a public health problem for which consequences are both immediate and long-term. These consequences are physical (cardiovascular diseases and musculoskeletal disorders), emotional (low self-esteem and depression), and social (increased stigma, social marginalization, and discrimination) [2].

In 2001 and 2002, the prevalence of overweight ranged from 3\% to 35\% among adolescents aged 13 years and $5 \%$ to $28 \%$ among adolescents aged 15 years in different European countries [3]. In the European countries studied to date, prevalence among boys was higher than that of same-age girls (except for 15 year olds in Ireland). In 2006, the European Union estimated the prevalence of overweight as $30.4 \%$ and obesity as $7.1 \%$ for youngsters aged 5 to 18 years [4]. In Luxembourg in 2005 and 2006, the prevalence of overweight children between 11 and 15 years of age was estimated to be 12.5\% [5]; for 11 year olds, the prevalence was $11 \%$ for girls and $14 \%$ for boys; for 13 year olds, it was $10 \%$ for girls and $15 \%$ for boys; and for 15 year olds, it was $9 \%$ for girls and $16 \%$ for boys [6]. These data from surveys conducted in schools reveal the extent of the problem but do not capture the influence of socioeconomic factors on the prevalence of overweight and obesity in children. The relationship between socioeconomic factors such as educational level, occupational status, and income and childhood obesity has been rigorously studied [7]-[27], yet this relationship has yet to be clearly established [15] [19] [20] [25].

A literature review [9] was conducted on the relationship between socioeconomic factors and childhood obesity between 1990 and 2005. Of the 45 studies included in this review, 19 demonstrated an inverse association between socioeconomic status and obesity, 14 found associations in subgroups, and 12 did not show any relationship. Fifteen of the 20 studies, however, revealed associations between educational level and childhood obesity.

The diversity of results is probably attributable to the exposure-measuring methodologies [15]. Authors define socioeconomic status in different ways: it may be defined by the educational level, professional category, income, or composite indices [21].

To determine the level of overweight and obesity, several BMI references have been employed [28]-[31]. Among these, the International Obesity Task Force (IOTF) curves are recommended for international comparisons, and are several other references to broaden possibilities for comparison [30] [31].

The aims of our study were: 1) to measure BMI and prevalence of overweight and obesity in children and 2) to measure the relationships between children's overweight or obese and parents' weight status and socioeconomic characteristics. This is a novel research approach in Luxembourg because it is based on data collected at the household level. Luxembourg, a founding member of the European Union, has very little, to our knowledge, information about children obesity and its socioeconomic determinants likely to promote international comparisons.

\section{Methods}

\subsection{Population}

This study's data were presented in the 2007 Socio-Economic Panel Liewen zu Lëtzebuerg/European UnionStatistics on Income and Living Conditions (PSELL/EU-SILC) survey on household income and living conditions. This survey covered 3885 households that were surveyed between February 2007 and July 2007, representing 10,419 people including 2519 children younger than 16 years of age. For this study, 775 children aged 7 to 12 years were included. Using a questionnaire, demographic and socioeconomic information on children and parents were collected. All items in the questionnaire concerned individual and household characteristics at the time of the survey, with the exception of revenue matters relating to the year preceding the survey.

\subsection{Measures}

The prevalence of overweight and obesity in children was measured using self-reported weight and height. BMI is calculated by dividing weight in kilograms by height in meters squared (weight/height ${ }^{2}$ ). In our study, only the IOTF references for comparison [31] were used.

For parents (adults who constitute the household, not necessarily biological parents), the value of BMI was 
self-reported but based on height, weight, and the interpretation of the investigator who visited the interviewee. The person should choose the value of BMI within a card. The investigator transcribes the questionnaire BMI as corresponding to the intersection of height and weight. For adults, World Health Organization references were used. Overweight was defined as having a BMI between 25 and 29.9, and obesity was defined as a BMI $\geq 30$.

Parents' weight status was also assessed, because it is assumed that parental weight reflects both the nature of genetic transmission and culture of overweight and obesity in children. This culture influences parent's choice of the food that will be available for their children. A variable of overweight status of parents was defined as following: parents are normal, at least one parent is obese, and at least one parent is in overweight.

\subsection{Socioeconomics Variables}

Parents' educational, occupational statuses and living conditions are considered. Parents' education level was classified by the highest level of education attained by the father and mother and was defined according to the International Standard Classification of Education (ISCED) in 3 classes: primary, secondary and tertiary education. The status of occupational activity (active or not) was used to consider time costs related to parents' foodrelated decisions and parents' ability to acquire quality food and provide recreational activities outside the home [32] [33]. Occupational statuses were defined as a dichotomous variable. For living conditions, we considered that individuals were in poverty when household's income was below $60 \%$ of the national median equivalised disposable income (Eurostat definition).

\subsection{Behaviour Variables}

Three household behaviour variables were considered in this study: physical activity, family eating habits, and following a diet.

Physical activity performed by parents is a categorical variable: both parents practise physical activity, only father practises physical activity, only mother practises physical activity, and none of parents practise physical activity. Parents' physical activity is likely to affect the behaviour of their children by encouraging them to participate in activities that can keep their weight under control.

The assessment of family eating habits by the father and/or mother: Parents rated their family diet as 1) very balanced; 2) more balanced; 3) rather unbalanced; 4) unbalanced; 5) it does not concern you; and 6) you do not know. This parameter was broken down into a dichotomous variable as follows. Diet was considered balanced if the parent (father and/or mother) identified with the first 2 descriptions. Diet was considered unbalanced if the parent (father and/or mother) identified with the other 4 descriptions.

The frequency of following a diet during the last 3 years preceding the survey was defined by interviewees in 1 of 4 ways: 1) yes, permanently; 2) yes, several times a year; 3$) 1$ to 3 times over the 3 years; and 4) not following a diet. These data were transformed into a single dichotomous variable as follows: the parent was considered to have completed a food regimen if he/she answered 1 of the first 3 terms, otherwise not diet.

\subsection{Socio Demographic Variables}

Adjustment variables were sex, age, and nationality of children (Table 1). Age was expressed as a categorical variable. Children's nationality was taken into account because of the high proportion of foreigners living in Luxembourg (42.9\% in 2010) [34].

\subsection{Statistical Analysis}

Two types of statistical analyses were conducted: 1) descriptive analysis with the socioeconomic distribution of the children's BMI; and 2) multilevel logistic regression.

1) An initial descriptive analysis was performed by calculating the mean BMI in children according to sex and then crossing children's BMI with socioeconomic characteristics of their parents. The $\chi^{2}$ test was used to assess the degree of significance.

2) We used a multilevel logistic regression with two levels to measure the relationship between overweight in children and socioeconomic characteristics of parents. The first level concerns the individual characteristic of children, and the second level is represented by the socioeconomic characteristic and overweight's risk factors for parents (level-household). Assuming that the probability to be overweight or obese may be statistically 
Table 1. Distribution of children’ BMI by socioeconomic characteristics.

\begin{tabular}{|c|c|c|c|c|c|c|c|c|c|}
\hline & \multicolumn{2}{|c|}{ Boys } & \multicolumn{4}{|c|}{ Girls } & \multicolumn{2}{|c|}{ Total } & \multirow[b]{2}{*}{$\mathrm{p}$} \\
\hline & $\mathrm{N}$ & Mean (Std) & $\mathrm{p}$ & $\mathrm{N}$ & Mean (Std) & $\mathrm{p}$ & $\mathrm{N}$ & Mean (Std) & \\
\hline \multicolumn{10}{|l|}{ Age (years) } \\
\hline $7-8$ & 113 & $16.7(2.7)$ & & 137 & $16.4(2.7)$ & & 250 & $16.5(2.7)$ & \\
\hline $9-10$ & 158 & $17.1(2.8)$ & & 132 & $16.7(2.6)$ & & 290 & $16.9(2.7)$ & \\
\hline $11-12$ & 123 & $18.6(4.0)$ & & 112 & $19.3(3.5)$ & & 235 & 18.9 (3.8) & \\
\hline \multicolumn{10}{|l|}{ Nationality } \\
\hline Luxembourgers & 228 & $16.8(3.8)$ & $* *$ & 203 & $17.0(4.1)$ & $*$ & 431 & $16.9(4.0)$ & ** \\
\hline Foreigners & 166 & $18.4(2.8)$ & & 178 & $17.8(2.5)$ & & 344 & $18.1(2.7)$ & \\
\hline \multicolumn{10}{|c|}{$\begin{array}{l}\text { Education level of } \\
\text { father }\end{array}$} \\
\hline Primary & 82 & $19.1(3.1)$ & ** & 96 & $19.0(2.8)$ & $* *$ & 177 & $19.0(2.9)$ & ** \\
\hline Secondary & 209 & $17.0(3.7)$ & & 193 & $17.0(3.7)$ & & 402 & $17.0(3.7)$ & \\
\hline Tertiary & 103 & $17.2(2.4)$ & & 92 & $16.5(2.4)$ & & 196 & $16.9(2.4)$ & \\
\hline \multicolumn{10}{|c|}{$\begin{array}{l}\text { Education level of } \\
\text { mother }\end{array}$} \\
\hline Primary & 97 & $18.9(3.3)$ & $* *$ & 111 & $18.1(3.3)$ & $* *$ & 207 & $18.5(3.3)$ & ** \\
\hline Secondary & 187 & $16.8(3.5)$ & & 187 & $17.4(3.6)$ & & 375 & $17.1(3.6)$ & \\
\hline Tertiary & 109 & $17.3(2.4)$ & & 82 & $16.1(2.0)$ & & 191 & $16.8(2.3)$ & \\
\hline \multicolumn{10}{|c|}{$\begin{array}{l}\text { Living conditions } \\
\text { (available income) }\end{array}$} \\
\hline In poverty & 56 & $18.6(2.7)$ & $*$ & 63 & $19.0(2.9)$ & ${ }^{* *}$ & 119 & $18.8(2.8)$ & ** \\
\hline Out poverty & 338 & $17.3(3.5)$ & & 318 & $17.0(3.2)$ & & 656 & $17.2(3.3)$ & \\
\hline \multicolumn{10}{|l|}{$\begin{array}{l}\text { Occupational } \\
\text { status if mother }\end{array}$} \\
\hline Works & 214 & $17.1(3.1)$ & * & 219 & $17.9(3.3)$ & * & 433 & $17.5(3.2)$ & \\
\hline Not works & 180 & $17.9(3.4)$ & & 162 & 16.7 (2.9) & & 342 & $17.3(3.2)$ & \\
\hline
\end{tabular}

Source: EU-SILC 2007, calculated by the authors. ${ }^{*}<0.05,{ }^{* *}<0.001$.

dependent on both the variance of individual characteristics (level 1) and the parent's characteristics (level 2), we considered a multilevel logistic regression analysis based on a logit link function and a function of binomial distribution [35]-[38].

Statistical analyses were performed using SAS Software 9.2, and all results were weighted with an effect relative to the sample size. The multilevel logistic regression models were carried out with the NLMIXED procedure [39].

\section{Results}

Table 1 presents the distribution of the mean BMI of girls and boys based on their age, nationality and parents' socioeconomic characteristics. The mean BMI of children was $17.4 \mathrm{~kg} / \mathrm{m}^{2}$ and ranged between $16.5 \mathrm{~kg} / \mathrm{m}^{2}$ and $18.9 \mathrm{~kg} / \mathrm{m}^{2}$. Children of foreign nationality have a mean BMI slightly higher than Luxembourg natives. Children whose parents only reached the primary level of education had a higher average BMI than those whose parents reached secondary and higher education. A slight social gradient was observed for all children, except when it comes to considering them separately by gender. Children belonging to households living below the poverty line had a higher average BMI $\left(18.8 \mathrm{~kg} / \mathrm{m}^{2}\right)$ than those belonging to households living above the poverty line $(17.2$ $\left.\mathrm{kg} / \mathrm{m}^{2}\right)$.

The mean BMI of children (girls and boys) was associated with their mother's employment status. The average BMI of boys whose mother did not work was higher than the BMI of boys whose mothers worked. However, the mean BMI of girls was higher when the mother worked. 
Table 2 shows the distribution of children's BMI by overweight's risk factors for the parents. When the parents were obese, mean BMI was higher regardless of the sex of the child. The BMI of children was also associated with parents' participation in physical activity. Children whose parents did not practice physical activity had a higher BMI. Parents' eating habits (referring to the balance of power and not the monitoring of diets) were associated with BMI in children. Mean BMI is higher among children whose parents rated their diet as unbalanced or who had followed a weight-loss program at least once during the 3 years preceding data collection.

Table 3 presents the results of the multilevel logistic regression of the probability to be in overweight or obese in depending socioeconomic characteristic and risk's factors for parents. The empty model established the variation by household in the probability to be in overweight or obese among children. The second-level variance (Random level 2) ranged from 24.14 in the empty model to 12.29 in the full model, but it is not statistically significant. Only nationality of children had significant effect on the probability to be in overweight or obese among the individual-level characteristics. Children of foreign nationality had 2.9 times more risk to be in overweight or obese than other children of Luxembourg nationality (OR $=2.90$, CI: 1.38 to 6.10$)$.

Among the household-level characteristics, only the coefficients of the fixed effects of the overweight status of parents were statistically significant. Children living in household with at least one parent is obese were 6.51 times more likely to be in overweight or obese compared to those in household with both parents are normal (OR $=6.51$, CI: 2.48 to 17.08), and those living in household with at least one parent is in overweight were 2.54 times more likely to be in overweight or obese compared to those in household with both parents are normal. Other household explanatory variables were not significantly associated with the probability to be in overweight or obese.

\section{Discussion}

Children aged 7 to 12 years, living in Luxembourg had, on an average, normal weight status compared with international standards of the IOTF [31]. There was no difference between girls' and boys' obesity prevalence, in contrast to findings in some European countries [2]. The prevalence of overweight is higher in boys regardless of age; this result was already observed in Luxembourg in people age 16 years and older [40].

Table 2. Distribution of children's BMI by overweight's risk factors for parents.

\begin{tabular}{|c|c|c|c|c|c|c|c|c|c|}
\hline & \multicolumn{2}{|c|}{ Boys } & \multirow[b]{2}{*}{$\mathrm{p}$} & \multicolumn{2}{|c|}{ Girls } & \multicolumn{4}{|c|}{ Total } \\
\hline & $\mathrm{N}$ & $\begin{array}{l}\text { Mean } \\
(\mathrm{Std})\end{array}$ & & $\mathrm{N}$ & $\begin{array}{l}\text { Mean } \\
(\text { Std) }\end{array}$ & $\mathrm{p}$ & $\mathrm{N}$ & $\begin{array}{l}\text { Mean } \\
(\mathrm{Std})\end{array}$ & $\mathrm{p}$ \\
\hline \multicolumn{10}{|l|}{ Overweight status of parents } \\
\hline At least one parent is obese & 121 & $19.1(3.9)$ & $<0.0001$ & 78 & $18.7(3.2)$ & $<0.0001$ & 199 & $18.9(3.6)$ & $<0.0001$ \\
\hline $\begin{array}{l}\text { At least one parent is in } \\
\text { overweight }\end{array}$ & 184 & $16.9(2.6)$ & & 186 & $16.8(3.1)$ & & 370 & $16.9(2.8)$ & \\
\hline Both parents are normal & 89 & $16.3(2.9)$ & & 113 & $17.2(2.9)$ & & 202 & $16.8(2.9)$ & \\
\hline \multicolumn{10}{|l|}{ Physical activity of parents } \\
\hline $\begin{array}{l}\text { Both parents practice physical } \\
\text { activity }\end{array}$ & 160 & $16.9(2.4)$ & 0.0015 & 157 & $16.3(2.8)$ & $<0.0001$ & 317 & $16.6(2.6)$ & $<0.0001$ \\
\hline $\begin{array}{l}\text { Only father practice physical } \\
\text { activity }\end{array}$ & 68 & $17.6(3.6)$ & & 52 & $17.5(2.4)$ & & 119 & $17.6(3.1)$ & \\
\hline $\begin{array}{l}\text { Only mother practices physical } \\
\text { activity }\end{array}$ & 61 & $16.7(2.9)$ & & 56 & $18.8(4.1)$ & & 117 & $17.7(3.7)$ & \\
\hline $\begin{array}{l}\text { None of parents practice Physical } \\
\text { activity }\end{array}$ & 105 & $18.6(3.7)$ & & 116 & $18.1(3.1)$ & & 222 & $18.3(3.4)$ & \\
\hline \multicolumn{10}{|l|}{ Family eating habits of parents } \\
\hline Balanced & 332 & $17.2(3.2)$ & 0.0003 & 329 & $17.3(3.0)$ & 0.3455 & 661 & $17.2(3.1)$ & 0.0027 \\
\hline Unbalanced & 60 & $18.9(3.5)$ & & 52 & $17.8(4.1)$ & & 113 & $18.4(3.8)$ & \\
\hline \multicolumn{10}{|l|}{ Following a diet by the parents } \\
\hline No diet & 267 & $17.0(3.3)$ & $<0.0001$ & 232 & $16.9(2.9$ & 0.0023 & 499 & $17.0(3.1)$ & $<0.0001$ \\
\hline Diet & 127 & 18.4 (3.1) & & 149 & 18.0 (3.6) & & 276 & $18.2(3.4)$ & \\
\hline
\end{tabular}

Source: EU-SILC 2007, calculated by the authors. 
Table 3. Multilevel logistic regression of the probability to be in overweight or obese in depending socioeconomic characteristic and risk's factors for parents.

\begin{tabular}{|c|c|c|c|c|}
\hline \multirow{2}{*}{ Fixed effects } & \multirow{2}{*}{$\begin{array}{c}\text { Model } 0 \\
\text { (Empty Model) }\end{array}$} & \multicolumn{3}{|c|}{ Model 1} \\
\hline & & Odds-Ratio (OR) & \multicolumn{2}{|c|}{ Confidence Interval (CI) 95\% } \\
\hline & & & & \\
\hline Intercept & 6.79 & 0.01 & 0.00 & 0.10 \\
\hline \multicolumn{5}{|l|}{ Sex } \\
\hline Boys & & ref. & & \\
\hline Girls & & 0.97 & 0.58 & 1.64 \\
\hline \multicolumn{5}{|l|}{ Age (years) } \\
\hline $11-12$ & & ref. & & \\
\hline $7-8$ & & 1.65 & 0.87 & 3.16 \\
\hline $9-10$ & & 1.9 & 0.62 & 2.26 \\
\hline \multicolumn{5}{|l|}{ Nationality } \\
\hline Luxembourgers & & ref. & & \\
\hline Foreigners & & $2.90^{*}$ & 1.38 & 6.10 \\
\hline \multicolumn{5}{|l|}{ Education level of father } \\
\hline Tertiary & & ref. & & \\
\hline Primary & & 2.85 & 0.90 & 8.99 \\
\hline Secondary & & 1.65 & 0.65 & 4.14 \\
\hline \multicolumn{5}{|l|}{ Education level of mother } \\
\hline Tertiary & & ref. & & \\
\hline Primary & & 2.38 & 0.73 & 7.69 \\
\hline Secondary & & 1.76 & 0.68 & 4.55 \\
\hline \multicolumn{5}{|l|}{ Living conditions (available income) } \\
\hline Out poverty & & ref. & & \\
\hline In poverty & & 1.02 & 0.51 & 2.03 \\
\hline \multicolumn{5}{|l|}{ Occupational status of mother } \\
\hline Works & & ref. & & \\
\hline Not works & & 1.09 & 0.62 & 1.93 \\
\hline \multicolumn{5}{|l|}{ Overweight status of parents } \\
\hline Both parents are normal & & ref. & & \\
\hline At least one parent is obese & & $6.51^{*}$ & 2.48 & 17.08 \\
\hline At least one parent is in overweight & & $2.54^{*}$ & 1.14 & 5.66 \\
\hline \multicolumn{5}{|l|}{ Physical activity of parents } \\
\hline Both parents practice physical activity & & ref. & & \\
\hline Only father practice physical activity & & 2.20 & 0.88 & 5.51 \\
\hline Only mother practice physical activity & & 2.61 & 0.98 & 6.97 \\
\hline None of parents practice Physical activity & & 2.14 & 0.93 & 4.93 \\
\hline \multicolumn{5}{|l|}{ Family eating habits of parents } \\
\hline Balanced & & ref. & & \\
\hline Unbalanced & & 0.67 & 0.32 & 1.43 \\
\hline \multicolumn{5}{|l|}{ Following a diet by the parents } \\
\hline No diet & & ref. & & \\
\hline Diet & & 1.01 & 0.55 & 1.86 \\
\hline \multicolumn{5}{|l|}{ Random effects } \\
\hline Level 2 : between household variation & 24.14 & 12.29 & 0.90 & 168.53 \\
\hline-2 log likelihood & 1367.9 & 668.70 & & \\
\hline
\end{tabular}

Source: EU-SILC 2007, calculated by the authors. ${ }^{*}$ significant figures $(\mathrm{p}<0.05)$. 
The relationship between socioeconomic factors of parents and BMI of children is identical to previous literature findings [15] [18]. Lioret and colleagues [18] showed that children aged 6 to 14 years have a lower risk of overweight when the socioeconomic status of the head of the household is higher (managers and professionals) or medium (employees, technicians) rather than low.

Nationality of children tends to represent in this relationship with BMI doubly disadvantaged [12]. Nationality affects parents' socioeconomic position, which influences overweight and obesity in children. In England, the prevalence of overweight was higher among foreigners than the general population [41]. Our results show a strong association between overweight and obesity of children and nationality, which reflects the fact that the probability to be in overweight or obese was 2.9 times higher in children of foreign nationality compared to children of Luxembourg nationality.

The education level of parents, especially the mother, and the health of children has been the subject of previous studies [27] [42]. Several studies have shown inverse relationships between the education level of parents (especially the mother) and BMI in children [9] [43]. In our study, these relationships exist from bivariate analysis. Therefore, these associations are not statistically significant with multivariate analysis.

Our results show that the parental weight status is associated with overweight or obesity in children. This association was more strongly when at least one parent is obese. These links reflect the genetic and cultural transmission of overweight and obesity from parents to children [41] [43] [44]. According to Anderson and colleagues [44], children of overweight mothers were approximately 3 points of percentage more likely to be obese, and children of obese mothers were 8 points of percentage more likely to be obese. Apart from a child's age, weight status of parents seems to have the strongest relationship with BMI or the fact to be in overweight or obese in children [41] [43] [45].

Overweight and obesity in children are linked to the image that parents reflect and behaviour they try to inculcate in their children, in particular, food habits and physical exercise [25] [46]. In our study, physical activity of the mother or father was not associated to the children's overweight or obesity.

Household eating habits are considered environmental factors that contribute to health inequalities [47] [48], particularly those relating to the weight of children [25] [26]. Indeed, parents are a child's first social referent, and they learn to love eating the food their parents eat or avoid eating the foods their parents do not eat [25]. Parents who regularly change their food choices and eating habits should be more attentive to the nutritional balance of the food to help control their child's weight [26]. In our study, the dietary habits of both parents were associated with BMI in girls. Children whose parents consider the household diet to be unbalanced are more likely to have higher a BMI. But, there are not significant association after adjusting by other variables

For the mother or father, following a diet during the 3 years before the study was a predictor of weight problems in the household and can be related to eating foods that are high in fat and/or low levels of physical activity. In our study, BMI was, on an average, higher among children living in households in which at least 1 parent reported that he/she was following a diet. However, multilevel logistic regression did not showed that relationship.

The relationship between the employment status of parents and children's weight status has been the subject of several studies during the past decade [32] [33] [45] [49]-[56]. There may be a positive and significant relationship between the average number of hours a mother works per week and overweight in children, but this relationship is not systematic and varies, depending on the age of children. For some authors [49]-[56], a child was more likely to be overweight and obese if his/her mother worked many hours per week. In contrast, Strauss and Knight [45] believe that children with parents who do not work are more likely to become obese than children with parents who have managerial occupations. In our study, multilevel logistic regression analysis led us to note the absence of statistically significant relationships between employment status of the mother and the probability to be overweight or obese.

The relationship between parents' socioeconomic status and overweight and obesity in children is relatively complex. Indeed, low socioeconomic status may lead to risky behaviours (poor diet, lack of physical activity, and sedentary lifestyle) and can result in obesity and overweight [24] [25]. Conversely, children living in relatively wealthy households are more likely to receive attention or special care from parents who offer a variety of physical and cultural activities and educate their children on the virtues of a healthy diet.

Our study' limitations primarily relate to data reporting regarding the weight and height of children and BMI of parents. Some studies suggest that parents tend to underestimate the problems of overweight and obesity in children [57]-[60], this situation is more pronounced when parents themselves are overweight. Despite the existence of such a risk, self-reported weight and height can reliably predict the prevalence of obesity and associated 
behaviours. The absence of data on physical activity or the degree of physical inactivity among children also was a limitation; migration behaviour is important when predicting overweight in adolescents [61].

\section{Conclusions}

Girls and boys have an average BMI that is identical and normal according to international classification systems. Our study shows the existence of statistically significant relationships between overweight's risk factors of parents and their children's obesity. It confirms that children's weight status is strongly influenced by family and social environment. Weight status of parents appears to be one of the main determinants of children's weight status. These links are relatively complex because they involve multiple dimensions (genetic, dietary behavioural, lifestyle, and education).

It is important to promote a healthy diet and regular physical activity early in life and to better educate parents about the likely consequences of overweight and obesity on children's health in adulthood.

\section{Acknowledgements}

This study received financial support from the Luxemburg National Research Fund (www.fnr.lu).

\section{References}

[1] Wang, Y. and Lobstein, T. (2006) Worldwide Trends in Childhood Overweight and Obesity. International Journal of Pediatric Obesity, 1, 11-25. http://dx.doi.org/10.1080/17477160600586747

[2] Nursing Best Practice Guidelines 2005.

[3] Carroquino, M. (2007) Prevalence of Excess Body Weight and Obesity in Children and Adolescents. Fact Sheet, ENHIS, No. 2.3.

[4] Jackson-Leach, R. and Lobstein T. (2006) Estimated Burden of Paediatric Obesity and Co-Morbidities in Europe. Part 1. The Increase in the Prevalence of Child Obesity in Europe Is Itself Increasing. International Journal of Pediatric Obesity, 1, 26-32. http://dx.doi.org/10.1080/17477160600586614

[5] OCDE (2009) Panorama de la santé 2009: Les indicateurs de l’OCDE. OCDE 2009.

[6] WHO (2008) Inegalities in Young People’s Health: Health Behaviour in School-Aged Children. International Report from the 2005/2006 Survey.

[7] Thibault, H., Contrand, B., Saubusse, E., Baine, M. and Maurice-Tison, S. (2010) Risk Factors for Overweight and Obesity in French Adolescents: Physical Activity, Sedentary Behavior and Parental Characteristics. Nutrition, 26, 192200. http://dx.doi.org/10.1016/j.nut.2009.03.015

[8] Expertise Collective (2006) Obésité: Bilan et évaluation des programmes de prévention et de prise en charge.

[9] Shrewsbury, V. and Wardle, J. (2008) Socioeconomic Status and Adiposity in Childhood: A Systematic Review of Cross-Sectional Studies 1990-2005. Obesity, 16, 275-284. http://dx.doi.org/10.1038/oby.2007.35

[10] Murasko, J. (2009) Socioeconomic Status, Height, and Obesity in Children. Economics \& Human Biology, 7, $376-386$. http://dx.doi.org/10.1016/j.ehb.2009.04.004

[11] Moreno, L.A., Tomás, C., González-Gross, M., Bueno, G., Pérez-González, J.M. and Bueno, M. (2004) Micro-Environmental and Socio-Demographic Determinants of Childhood Obesity. International Journal of Obesity, 28, S16-S20. http://dx.doi.org/10.1038/sj.ijo.0802798

[12] Waters, E., Ashbolt, R., Gibbs, L., Booth, M., Magarey, A., Gold, L., et al. (2008) Double Disadvantage: The Influence of Ethnicity over Socioeconomic Position on Childhood Overweight and Obesity: Findings from an Inner Urban Population of Primary School Children. International Journal of Pediatric Obesity, 3, 196-204. http://dx.doi.org/10.1080/17477160802141846

[13] Langnäse, K., Mast, M., Danielzik, S., Spethmann, C. and Müller, M.J. (2003) Socioeconomic Gradients in Body Weight of German Children Reverse Direction between the Ages of 2 and 6 Years. Journal of Nutrition, 133, 789-796.

[14] Singh, G.K., Siahpush, M. and Kogan, M.D. (2010) Rising Social Inequalities in US Childhood Obesity, $2003-2007$. Annals of Epidemiology, 20, 40-52. http://dx.doi.org/10.1016/j.annepidem.2009.09.008

[15] Verger, P., Saliba, B., Guagliardo, V., Bouhnik, A.D., Eichenbaum-Voline, S. and Groupe EVALMATER (2007) Individual Social Characteristics, Municipal Environment and the Prevalence of Weight Problems in Early Childhood: A Multilevel Analysis. Revue d'Épidémiologie et de Santé Publique, 55, 347-356. http://dx.doi.org/10.1016/j.respe.2007.06.003

[16] De Spiegelaere, M., Dramaix, M. and Hennart, P. (1998) Social Class and Obesity in 12-Year-Old Children in Brussels: 
Influence of Gender and Ethnic Origin. European Journal of Pediatrics, 157, 432-435. http://dx.doi.org/10.1007/s004310050845

[17] Sweeting, H., West, P. and Young, R. (2008) Obesity among Scottish 15 Year Olds 1987-2006: Prevalence and Associations with Socio-Economic Status, Well-Being and Worries about Weight. BMC Public Health, 8, 404. http://dx.doi.org/10.1186/1471-2458-8-404

[18] Lioret, S., Maire, B., Volatier, J.L. and Charles, M.A. (2007) Child Overweight in France and Its Relationship with Physical Activity, Sedentary Behaviour and Socioeconomic Status. European Journal of Clinical Nutrition, 61, 509516.

[19] Stamatakis, E., Primatesta, P., Chinn, S., Rona, R. and Falascheti, E. (2005) Overweight and Obesity Trends from 1974 to 2003 in English Children: What Is the Role of Socioeconomic Factors? Archives of Disease in Childhood, 90, 9991004. http://dx.doi.org/10.1136/adc.2004.068932

[20] Wang, Y. (2001) Cross-National Comparison of Childhood Obesity: The Epidemic and the Relationship between Obesity and Socioeconomic Status. International Journal of Epidemiology, 30, 1129-1136. http://dx.doi.org/10.1093/ije/30.5.1129

[21] Stamatakis, E., Wardle, J. and Cole, T.J. (2010) Childhood Obesity and Overweight Prevalence Trends in England: Evidence for Growing Socioeconomic Disparities. International Journal of Obesity, 34, 41-47. http://dx.doi.org/10.1038/ijo.2009.217

[22] O’Dea, J.A. (2008) Gender, Ethnicity, Culture and Social Class Influences on Childhood Obesity among Australian Schoolchildren: Implications for Treatment, Prevention and Community Education. Health \& Social Care in the Community, 16, 282-290. http://dx.doi.org/10.1111/j.1365-2524.2008.00768.x

[23] Drenowatz, C., Eisenmann, J.C., Pfeiffer, K.A., Welk, G., Heelan, K., Gentile, D. and Walsh, D. (2010) Influence of Socio-Economic Status on Habitual Physical Activity and Sedentary Behavior in 8- to 11-Year Old Children. BMC Public Health, 10, 214. http://dx.doi.org/10.1186/1471-2458-10-214

[24] Singh, G.K., Kogan, M.D., Van Dyck, P.C. and Siahpush, M. (2008) Racial/Ethnic, Socioeconomic, and Behavioral Determinants of Childhood and Adolescent Obesity in the United States: Analyzing Independent and Joint Associations. Annals of Epidemiology, 18, 682-695. http://dx.doi.org/10.1016/j.annepidem.2008.05.001

[25] Davison, K.K. and Birch, L.L. (2001) Child and Parent Characteristics as Predictors of Change in Girls' Body Mass Index. International Journal of Obesity, 25, 1834-1842. http://dx.doi.org/10.1038/sj.ijo.0801835

[26] Klohe-Lehman, D.M., Freeland-Graves, J., Clarke, K.K., Cai, G., Voruganti, V.S., Milani, T.J., Nuss, H.J., Proffitt, J.M. and Bohman, T.M. (2007) Low-Income, Overweight and Obese Mothers as Agents of Change to Improve Food Choices, Fat Habits, and Physical Activity in Their 1-to-3-Year-Old Children. Journal of the American College of Nutrition, 26, 196-208. http://dx.doi.org/10.1080/07315724.2007.10719602

[27] Thomas, D., Strauss, J. and Henriques, M.H. (1991) How Does Mother's Education Affect Child Height. The Journal of Human Resources, 26, 183-211. http://dx.doi.org/10.2307/145920

[28] Rolland-Cachera, M. (2004) Définitions actuelles de l'obésité de l'enfant. Sang Thrombose Vaisseaux, 16, $187-192$.

[29] Castetbon, K. and Rolland-Cachera, M. (2000) Surpoids et obésité chez les enfants de 7 à 9 ans. INVS, Saint-Maurice.

[30] Rolland-Cachera, M.F., Péneau, S. and Castetbon, K. (2007) Définition de l’obésité de l'enfant: Les différentes courbes de référence. Le Concours Médical, 129, 1171-1174.

[31] Cole, T., Bellizzi, M., Flegal, K. and Dietz, W. (2000) Establishing a Standard Definition for Child Overweight and Obesity Worldwide: International Survey. British Medical Journal, 320, 1240. http://dx.doi.org/10.1136/bmj.320.7244.1240

[32] Anderson, P.M., Butcher, K.F. and Levine, P.B. (2003) Maternal Employment and Overweight Children. Journal of Health Economics, 22, 477-504. http://dx.doi.org/10.1016/S0167-6296(03)00022-5

[33] Anderson, P.M. and Butcher, K.F. (2006) Childhood Obesity: Trends and Potential Causes. Future of Children, 16, 1945. http://dx.doi.org/10.1353/foc.2006.0001

[34] Statec (2010) Luxembourg in Figures. http://www.statistiques.public.lu/catalogue-publications/luxembourg-en-chiffres/luxembourg-figures.pdf

[35] Snijders, T. and Bosker, R. (1999) Multilevel Analysis: An Introduction to Basic and Advanced Multilevel Modeling. Sage Publications, London.

[36] Snijders, T. and Bosker, R. (2011) Multilevel Analysis: An Introduction to Basic and Advanced Multilevel Modeling. 2nd Edition, Sage Publications, London.

[37] Guo, G. and Zhao, H.X. (2000) Multilevel Modeling for Binary Data. Annual Review of Sociology, 26, 441-462. http://dx.doi.org/10.1146/annurev.soc.26.1.441 
[38] Li, B., Lingsma, H.F., Steyerberg, E.W. and Lesaffre, E. (2011) Logistic Random Effects Regression Models: A Comparison of Statistical Packages for Binary and Ordinal Outcomes. BMC Medical Research Methodology, 11, 77. http://www.biomedcentral.com/1471-2288/11/77 http://dx.doi.org/10.1186/1471-2288-11-77

[39] SAS Institute Inc. (2007) NLMIXED Procedure, SAS 9.2. Cary.

[40] Tchicaya, A. and Lorentz, N. (2010) Prévalence du surpoids et de l'obésité de 1995 à 2008. Collection Vivre au Luxembourg, 66, 2. CEPS/INSTEAD, Differdange, Luxembourg.

[41] Craig, R. and Mindell, J. (2008) Health Survey for England 2006. Vol 2. Obesity and Other Risk Factors in Children. National Centre for Social Research, London.

[42] Grossman, M. (1972) On the Concept of Health Capital and the Demand for Health. Journal of Political Economy, 80, 223-255. http://dx.doi.org/10.1086/259880

[43] Lazzeri, G., Pammolli, A., Pilato, V. and Giacchi, M.V. (2011) Relationship between 8/9-yr-Old School Children BMI, Parents’ BMI and Educational Level: A Cross Sectional Survey. Nutrition Journal, 10, 76. http://dx.doi.org/10.1186/1475-2891-10-76

[44] Anderson, P.M., Butcher, K.F. and Levine, P.B. (2000) Maternal Employment and Overweight Children. NBER Working Paper, National Bureau of Economic Research, Inc., MA, USA.

[45] Strauss, R. and Knight, J. (1999) Influence of the Home Environment on the Development of Obesity in Children. Pediatrics, 103, e85. http://pediatrics.aappublications.org/content/103/6/e85.full.html http://dx.doi.org/10.1542/peds.103.6.e85

[46] Steinbeck, K.S. (2001) The Importance of Physical Activity in the Prevention of Overweight and Obesity in Childhood: A Review and an Opinion. Obesity Reviews, 2, 117-130. http://dx.doi.org/10.1046/j.1467-789x.2001.00033.x

[47] Dowler, E. (2001) Inequalities in Diet and Physical Activity in Europe. Public Health Nutrition, 4, 701-709. http://dx.doi.org/10.1079/PHN2001160

[48] Darmon, N. and Drewnowski, A. (2008) Does Social Class Predict Diet Quality? American Journal of Clinical Nutrition, 87, 1107-1117.

[49] Morrissey, T.W., Dunifon, R.E. and Kalil, A. (2001) Maternal Employment, Work Schedules, and Children’s Body Mass Index. Child Development, 82, 66-81. http://dx.doi.org/10.1111/j.1467-8624.2010.01541.x

[50] Stewart, L., Liu, Y. and Rodriguez, E. (2012) Maternal Unemployment and Childhood Overweight: Is There a Relationship? Journal of Epidemiology \& Community Health, 66, 641-646. http://dx.doi.org/10.1136/jech.2010.110718

[51] Champion, S.L., Rumbold, A.R., Steele, E.J., Giles, L.C., Davies, M.J. and Moore, V.M. (2012) Parental Work Schedules and Child Overweight and Obesity. International Journal of Obesity, 36, 573-580. http://dx.doi.org/10.1038/ijo.2011.252

[52] Liu, E., Hsiao, C., Matsumoto, T. and Chou, S. (2008) Maternal Full-Time Employment and Overweight Children: Parametric, Semi-Parametric, and Non-Parametric Assessment. Working Paper, Department of Economics, University of Southern California, Los Angeles, USA.

[53] Bishop, J. (2010) The Effect of Maternal Employment on Youth Overweight and Obesity. Preliminary Paper Prepared for the Australian Conference of Economists, September 2010. http://www.melbourneinstitute.com/downloads/hilda/Bibliography/Conference_Papers/Bishop_ACE10-135.pdf

[54] Araneo, J. (2008) The Effect of Maternal Employment on Childhood Obesity in United Stated. Working Papers. http://crcw.princeton.edu/workingpapers/WP08-13-FF.pdf

[55] Garcia, E., Labeaga, J.M. and Ortega, C. (2006) Maternal Employment and Childhood Obesity in Spain. Working Paper, FEDEA, Madrid.

[56] Fertig, A., Glomm, G. and Tchernis, R. (2009) The Connection between Maternal Employment and Childhood Obesity: Inspecting the Mechanism. Review of Economics of the Household, 7, 227-255. http://dx.doi.org/10.1007/s11150-009-9052-y

[57] Jeffery, A.N., Voss, L.D., Metcalf, B.S., Alba, S. and Wilkin, T.J. (2005) Parents' Awareness of Overweight in Themselves and Their Children: Cross Sectional Study within a Cohort. British Medical Journal, 330, 23-24. http://dx.doi.org/10.1136/bmj.38315.451539.F7

[58] Eckstein, K.C., Mikhail, L.M., Ariza, A.J., Thomson, J.S., Millard, S.C., Binns, H.J. and Pediatric Practice Research Group (2006) Parents' Perceptions of Their Child’s Weight and Health. Pediatrics, 117, 681-690. http://dx.doi.org/10.1542/peds.2005-0910

[59] He, M. and Evans, A. (2007) Les parents sont-ils conscients que leurs enfants souffrent de surpoids ou d’obésité? Canadian Family Physician, 53, 1493-1499.

[60] Doolen, J., Alpert, P.T. and Miller, S.K. (2009) Parental Disconnect between Perceived and Actual Weight Status of 
Children: A Metasynthesis of the Current Research. Journal of the American Academy of Nurse Practitioners, 21, 160166. http://dx.doi.org/10.1111/j.1745-7599.2008.00382.x

[61] Wardle, J., Paramenter, K. and Waller, J. (2000) Nutrition Knowledge and Food Intake. Appetite, 34, 269-275. http://dx.doi.org/10.1006/appe.1999.0311 
Scientific Research Publishing (SCIRP) is one of the largest Open Access journal publishers. It is currently publishing more than 200 open access, online, peer-reviewed journals covering a wide range of academic disciplines. SCIRP serves the worldwide academic communities and contributes to the progress and application of science with its publication.

Other selected journals from SCIRP are listed as below. Submit your manuscript to us via either submit@scirp.org or Online Submission Portal.
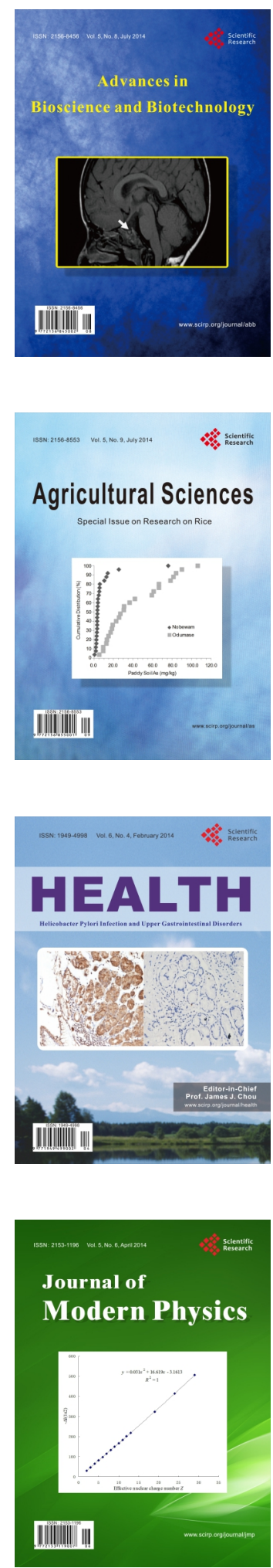
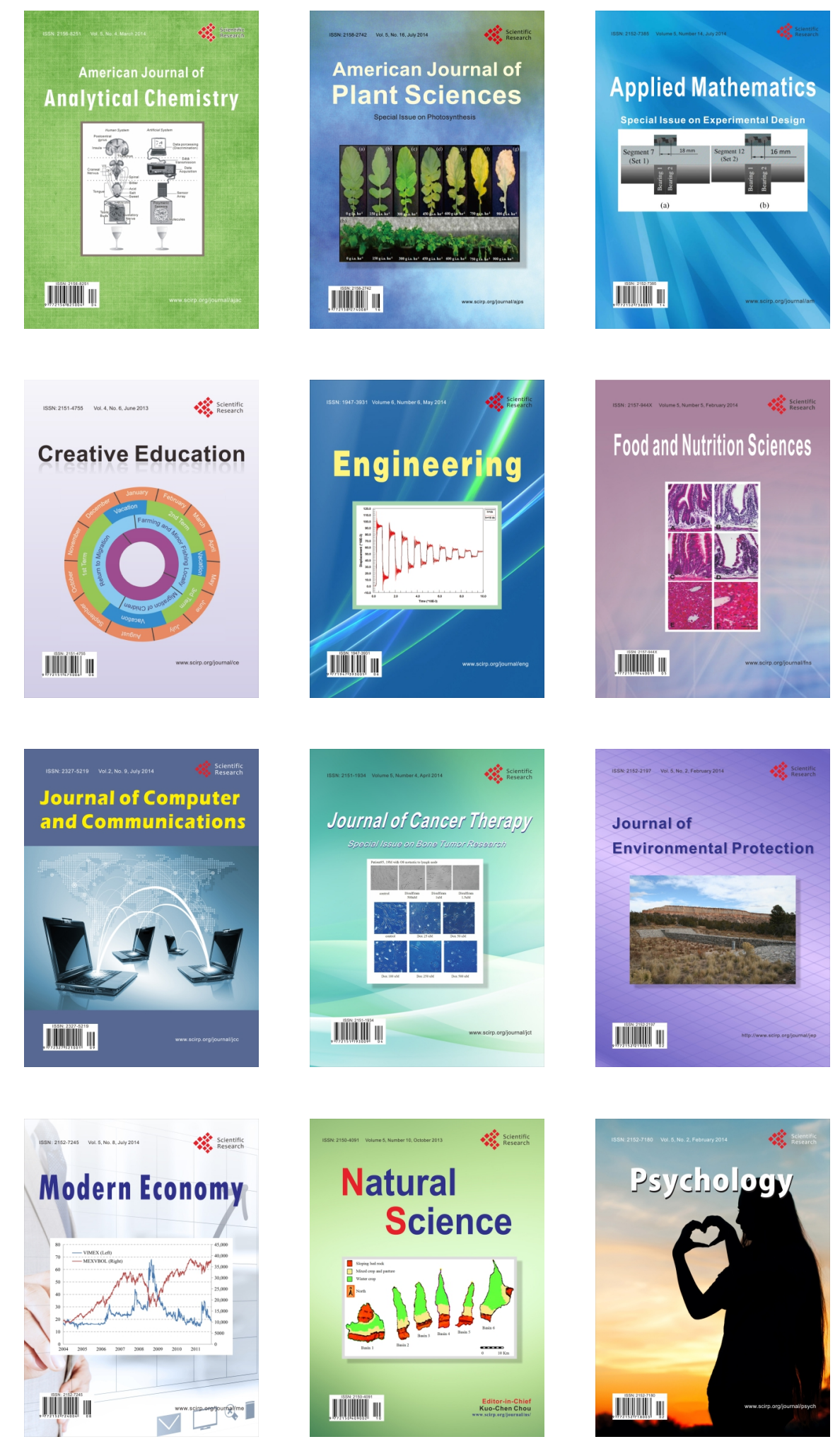